ISSN : 2580-3220, E-ISSN : 2580-4588

J. Mandiri., Vol. 4, No. 2, Desember 2020 (199 - 209)

C2018 Lembaga Kajian Demokrasi

dan Pemberdayaan Masyarakat (LKD-PM)

DOI : https://doi.org/10.33753/mandiri.v4i2.127

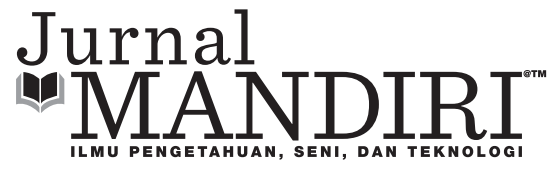

\title{
Pengaruh Tingkat Pendidikan, Tingkat Literasi Keuangan, dan Instrumen Literasi Keuangan Terhadap Keputusan Pembelian Pada Media Online (Studi Kasus Masyarakat Kota Tangerang Selatan)
}

\author{
Diana Riyana Harjayanti \\ Fakultas Ekonomi, Universitas Pamulang \\ dharjayanti@yahoo.com \\ Angga Rovita \\ anggarovita@gmail.com \\ Fakultas Ekonomi, Universitas Pamulang \\ Teguh Yuwono \\ teguh.yuwono9@yahoo.co.id \\ Fakultas Ekonomi, Universitas Pamulang
}

\begin{abstract}
Abstrak
Perkembangan teknologi digital dan trend e-commerce menyebabkan perubahan pola belanja masyarakat yang awalnya bersifat konvensional offline beralih ke pola belanja online melalui web/blog. Sehingga dalam penelitian ini, penulis tertarik untuk meneliti apakah ada pengaruh dari tingkat pendidikan, tingkat literasi keuangan, dan instrumen literasi keuangan pada keputusan pembelian terhadap media online dengan studi kasus pada masyarakat di Kota Tangerang Selatan. Metode penelitian yang digunakan adalah deskritif kuantitatif dengan melakukan pengolahan data dan analisa yang diperoleh dari hasil survey terhadap sample dari populasi masyarakat di Kota Tangerang Selatan. Hasil yang diperoleh dari survei yang dilakukan pada masyarakat daerah Kota Tangerang Selatan adalah faktor efisiensi dan faktor harga yang lebih murah dianggap sebagai faktor yang paling berpengaruh dalam keputusan pembelian pada media online. Keuntungan transaksi belanja yang ditawarkan melalui media online terutama selama pandemic covid ini menyebabkan banyak masyarakat yang mengubah pola belanja offline menjadi online untuk membeli barang yang diperlukan. Hal ini diperkuat dengan hasil yang diperoleh dari penelitian bahwa faktor tingkat pendidikan dan literasi keuangan tidak mempengaruhi keputusan pembelian pada media online di masyarakat Kota Tangerang Selatan baik secara partial (Uji t) maupun simultan (Uji F) dengan nilai sig $>0,05$.
\end{abstract}

Kata Kunci : Tingkat Pendidikan, Tingkat Literasi Keuangan, Instrumen Literasi Keuangan, Keputusan Pembelian Pada Media Online

\begin{abstract}
The development of digital technology and the trend of e-commerce cause changes in people's shopping patterns that in beginning is offline conventional to switch to online shopping through web/ blogs. So that in this study, the authors are interested in examining whether there is an influence from the level of education, the level of financial literacy, financial literacy instruments on purchasing decisions in online media with a case study on the community in the South Tangerang City. The research method used is descriptive quantitative by processing data and analysis obtained from a survey of a sample of the population in the South Tangerang City. The results obtained from the survey conducted on the people of the South Tangerang City were the efficiency factor and
\end{abstract}


the cheaper price factor were considered the most influential factors in purchasing decisions on online media. The advantages of shopping transactions offered through online media, especially during the Covid pandemic, have caused many people to change their offline shopping patterns to online to buy the items they need. This is also reinforced by the results of research from the hypothesis test which concludes that the level of education, the level of financial literacy and financial literacy instruments do not affect the value of purchasing decisions on online media in South Tangerang City society either partially ( $t$ test) or simultaneously (F test). sig value $>0.05$.

Keywords : Education Level, Financial Literacy Level, Financial Literacy Instruments, Online Media Purchasing Decisions

\section{PENDAHULUAN}

Semakin pesatnya perkembangan era digital saat ini menyebabkan perubahan model bisnis perusahaan. Perusahaan yang tidak cepat menyesuaikan dengan perkembangan teknologi dalam menjalankan bisnisnya akan mengalami kegagalan. Seperti beberapa perusahaan ritail yang mulai menutup beberapa gerai tokonya, seiring dengan perubahan trend pembelian pelanggan yang cenderung menggunakan media online dibanding mendatangi langsung gerai penjualan.

Berbagai kemudahan ditawarkan ke konsumen dalam melakukan transaksi jual beli melalui media online seperti efisiensi, kecepatan, informasi, dan variasi produk yang beragam dan kemudahan tanpa hambatan yang berarti. Sedangkan keuntungan bagi perusahaan yang melakukan transaksi bisnisnya melalui media online, antara lain memudahkan manajemen dalam membangun dan memelihara hubungan bisnisnya dengan konsumen, memudahkan dan memperluas jangkauan promosi produk serta memudahkan dalam berkomunikasi dengan konsumen.

Namun pembelian secara online juga memiliki banyak risiko. Di antaranya produk yang dipesan tidak sesuai dengan gambar yang ditampilkan, kerusakan dari barang yang diterima, kesalahan order, dan tidak terkirimnya barang yang dipesan karena hilang/terlambat.

Perubahan trend pembelian konvensional ke media online perlu diimbangi dengan pengetahuan konsumen terhadap proses dan produk yang ditawarkan pada media online. Dengan demikian masyarakat dapat memahami keuntungan dan risiko dalam melakukan aktivitas pembelian pada media online. Oleh karena itu, tingkat literasi keuangan dan tingkat pendidikan menjadi salah satu penentu bagi konsumen dalam kebijakan pengelolaan keuangan keluarga dan alat filter dalam keputusan pembelian terutama pada media online.

Beberapa penelitian sebelumnya telah melakukan pengamatan terhadap tema yang terkait dengan penelitian ini. Misalnya, penelitian yang dilakukan Lina Aryani (2016) mengenai faktor yang mempengaruhi konsumen terhadap keputusan pembelian secara online pada toko online Lazada. Adapun yang mempengaruhinya antara lain faktor produk, kepercayaan, dan pelayanan.

Penelitian dilakukan Fuad Abdul Fattah, Mintasih Indriayu, dan Sunarto (2018). Terdapat pengaruh yang negatif dan signifikan antara literasi keuangan terhadap perilaku konsumtif siswa SMA Muhammadiyah 1 Karaganyar.

Selain itu penelitian yang dilakukan Samuel Wahyu Hari Christoper dan Ika Kristiante (2020), di mana ada pengaruh E-Commerce dan literasi keuangan terhadap kelangsungan suatu usaha. Sedangkan penelitian yang dilakukan oleh Lo, Louis Yi-Shih, Sheng-Wei Lin, dan Li-Yi Hsu (2016), menunjukkan bahwa desain dari online shop dan promosi yang diberikan dapat menstimulasi keputusan pembelian online.

Dari latar belakang tersebut peneliti tertarik untuk meneliti sejauh mana pengaruh tingkat pendidikan, tingkat literasi keuangan, dan instrumen literasi keuangan terhadap keputusan pembelian pada media online dengan melakukan studi kasus pada masyarakat di Kota Tangerang Selatan. Pemilihan Kota Tangerang Selatan sebagai objek penelitian atas pertimbangan lokasinya sebagai daerah berkembang yang dekat dengan pusat ibukota. Sehingga informasi dan 
teknologi cenderung mengikuti trend masyarakat di ibukota.

Pada penelitian ini dilakukan penyebaran kuesioner dengan responden penelitian yaitu masyarakat yang berdomilisi di Kota Tangerang Selatan. Adapun batasan usia 15-45 tahun, pria dan wanita, mempunyai perangkat akses media online minimal 1, dan tingkat pendidikan SMP ke atas. Penilaian kuisioner menggunakan 5 skala likert di mana skala 1 adalah sangat tidak setuju dan skala 5 sangat setuju. Kemudian kerangka berpikir yang menjadi peta dalam penelitian ini sebagai berikut:

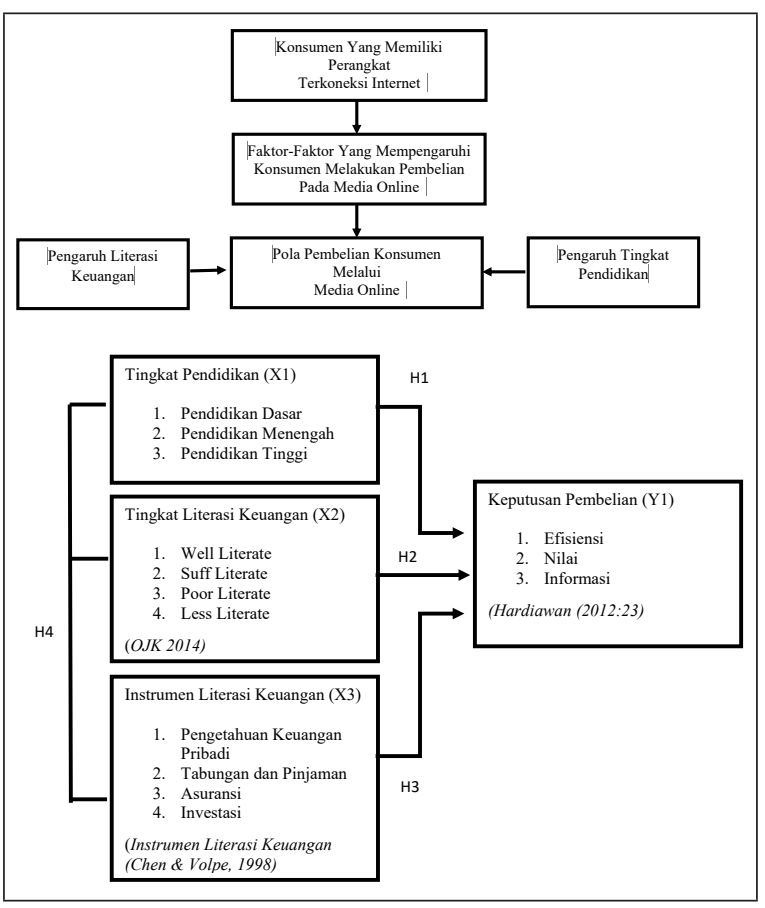

Gambar 1. Kerangka Berpikir Penelitian

\section{METODE}

Jenis penelitian yang dilakukan yaitu penelitian deskritif kuantitatif dengan melakukan pengolahan data dan analisa yang diperoleh dari wawancara dan hasil survei terhadap sampel dari populasi masyarakat di Kota Tangerang Selatan. Subjek penelitian yaitu informan dari masyarakat yang berdomilisi di Kota Tangerang Selatan dengan batasan usia 15-45 tahun, pria dan wanita serta mempunyai perangkat akses media online minimal 1 dan tingkat pendidikan SMP ke atas. Objek penelitian adalah segala bentuk pembelian yang dilakukan oleh informan yang melakukan pembelian dengan menggunakan media online.
Selanjutnya variabel bebas dalam penelitian yaitu tingkat pendidikan, tingkat literasi keuangan, dan instrumen literasi keuangan. Sedangkan variabel terikat yaitu keputusan pembelian pada media online.

Data primer merupakan data yang diperoleh dari hasil wawancara dan survei langsung terhadap subjek penelitian. Data sekunder merupakan data yang diperoleh dari hasil studi pustaka, jurnal, majalah, dan internet sebagai data pendukung penelitian.

Dalam memperoleh data penelitian maka diperlukan beberapa metode. Observasi yaitu dengan melakukan pengamatan langsung terhadap subjek dan objek penelitian. Dengan melakukan observasi, maka peneliti dapat merasakan dan mengamati kejadian yang telah terjadi sebenarnya. Wawancara yaitu melalukan memperoleh informasi secara langsung dari sumbernya. Kemudian dokumentasi dengan cara mengumpulkan data dari studi pustaka, jurnal, internet, dan video yang akan menjadi sumber bagi peneliti dalam melakukan analisis.

\section{HASIL dan PEMBAHASAN Hasil}

Karakteristik responden dalam penelitian ini penduduk yang tinggal di Kota Tangerang Selatan. Jumlah populasi penduduk Kota Tangerang Selatan yakni 1.799.605 jiwa. Jumlah minimal responden yang dijadikan sampel dalam penelitian ini dengan menggunakan metode Slovin yaitu:

$$
n=\frac{N}{1+N e^{2}}
$$

Dengan menggunakan ukuran populasi $\mathrm{N}$ $=1.799 .605$, e adalah margin of error yang digunakan 15\% merupakan besaran kesalahan yang ditetapkan.

$$
n=\frac{1.799 .605}{1+\left(1.799 .605 \times 0.15^{2}\right)}=44
$$

Karena jumlah responden yang masuk adalah sebanyak 52 orang maka jumlah minimal responden sebenayak 44 sudah terpenuhi.

Sedangkan untuk karateristik responden terdiri dari jenis kelamin dan tingkat pendidikan. 
Jenis Kelamin Responden

\begin{tabular}{|c|c|c|}
\hline \multicolumn{3}{|c|}{ Tabel 1. Responden Berdasarkan Gender } \\
\hline Gender & Total & $\%$ \\
\hline Laki-laki & 18 & $35 \%$ \\
\hline Perempuan & 34 & $65 \%$ \\
\hline Grand Total & 52 & $100 \%$ \\
\hline
\end{tabular}

Berdasarkan data di atas, responden dengan jenis kelamin laki-laki sebanyak 18 orang atau sebesar 35\%. Sedangkan jenis kelamin perempuan sebanyak 34 orang atau sebesar $65 \%$.

Jenis Pendidikan Responden

\begin{tabular}{|c|c|c|}
\hline \multicolumn{3}{|c|}{ Tabel 2. Responden Berdasarkan Tingkat Pendidikan } \\
\hline Pendidikan & Total & $\%$ \\
\hline Pendidikan Tinggi (S1, S2, S3) & 26 & $50 \%$ \\
\hline Pendidikan Menengah (SMA) & 20 & $38 \%$ \\
\hline Pendidikan Dasar (SD,SMP) & 6 & $12 \%$ \\
\hline Grand Total & 52 & $100 \%$ \\
\hline
\end{tabular}

Berdasarkan data dari 52 responder dengan tingkat pendidikan S3 sebanyak 1 orang atau sebesar $2 \%$, S2 sebanyak 16 orang atau sebesar $31 \%$, S1 sebesar 9 orang atau sebesar 17\%, SMA sebanyak 20 orang atau sebesar $38 \%$, dan SMP sebanyak 6 orang atau sebesar $12 \%$.

\section{Tingkat Literasi Keuangan}

Dalam melakukan kategori Tingkat Literasi Keuangan, kategori yang digunakan yaitu Tingkat Literasi Keuangan (OJK 2014) dan Instrumen Literasi Keuangan (Chen \& Volpe, 1998).

\begin{tabular}{|c|c|}
\hline \multicolumn{2}{|c|}{ Tabel 3. Tabel Kategori Tingkat Literasi Keuangan } \\
\hline Tingkat Literasi Keuangan & Indikator \\
\hline Well Literate & $100 \%-81 \%$ Benar \\
\hline Suff Literate & $80 \%-61 \%$ Benar \\
\hline Less Literate & $60 \%-31 \%$ Benar \\
\hline Not Literate & $30 \%$ Kebawah \\
\hline Sumber : 0JK 2014) dan Instrumen Literasi Keuangan (Chen \& Volpe, 1998) \\
\hline
\end{tabular}

Selanjutnya, dari data 52 responden dibagi menjadi kategori sebagai berikut:

\begin{tabular}{|c|c|c|}
\hline \multicolumn{3}{|c|}{ Tabel 4. Tabel Kategori Tingkat Literasi } \\
\hline Tingkat Literasi Keuangan & Total & $\%$ \\
\hline Well Literate $(81 \%-100 \%)$ & 1 & $2 \%$ \\
\hline Suff Literate $(61 \%-80 \%)$ & 17 & $33 \%$ \\
\hline Less Literate $(31 \%-60 \%)$ & 33 & $63 \%$ \\
\hline Not Literate (30\% kebawah) & 1 & $2 \%$ \\
\hline & 52 & $100 \%$ \\
\hline
\end{tabular}

Sedangkan dari 52 orang responden, untuk tingkat literasi keuangan Well Literate dengan total jawaban yang benar dari soal yang diberikan $81 \%-100 \%$ sebanyak 1 orang atau $2 \%$ dari total responden. Untuk tingkat literasi keuangan Suff Literate dengan total jawaban yang benar dari soal yang diberikan $61 \%-80 \%$ sebanyak 17 orang atau 33\% dari total responden. Tingkat literasi keuangan Less Literate dengan total jawaban yang benar dari soal yang diberikan 31\%-60\% sebanyak 33 orang atau $63 \%$ dari total responden. Sedangkan tingkat literasi keuangan Not Literate dengan total jawaban yang benar dari soal yang diberikan di bawah $30 \%$ sebanyak 1 orang atau $2 \%$ dari total responden.

Metode penilaian atau deskriptif variabel penelitian dalam penelitian ini yaitu variabel telah ditetapkan secara spesifik oleh peneliti, yang selanjutnya disebut sebagai variabel penelitian. Sebelum dilakukan analisis, terlebih dahulu dilakukan pembobotan terhadap skor masing-masing variabel dengan memberikan skor total dengan jumlah item dari variabel yang dibobot, melalui pertanyaaan yang diberikan peneliti dalam kuesioner. Pembobotan dalam penelitian ini menggunakan metode pengukuran Likert, di mana pernyataan mengandung 5 alternatif jawaban dengan menentukan rentang skala dari setiap variabel dapat ditetapkan interval untuk memberikan interpretasi berdasarkan baik dan tidak baik, sebagai berikut:

\begin{tabular}{|c|l|}
\hline \multicolumn{2}{|c|}{ Tabel 5. Tabel Kriteria Tanggapan Responden } \\
Rentang Skala & \multicolumn{1}{c|}{ Keterangan/Kriteria } \\
\hline $1,00-1,790$ & Sangat Tidak Setuju/Sangat Tidak Baik \\
\hline $1,80-2,59$ & Tidak Setuju/Tidak Baik \\
\hline $2,60-3,39$ & Kurang Setuju/Kurang Baik \\
\hline $3,40-4,19$ & Setuju/Baik \\
\hline $4,19-5,00$ & Sangat Setuju/Sangat Baik \\
\hline & \\
\hline
\end{tabular}

\section{Instrumen Literasi Keuangan}

Kriteria obyek yang diteliti berdasarkan tanggapan responden pada butir pertanyaan variabel instrument literasi keuangan yang diberikan sebagai berikut: 


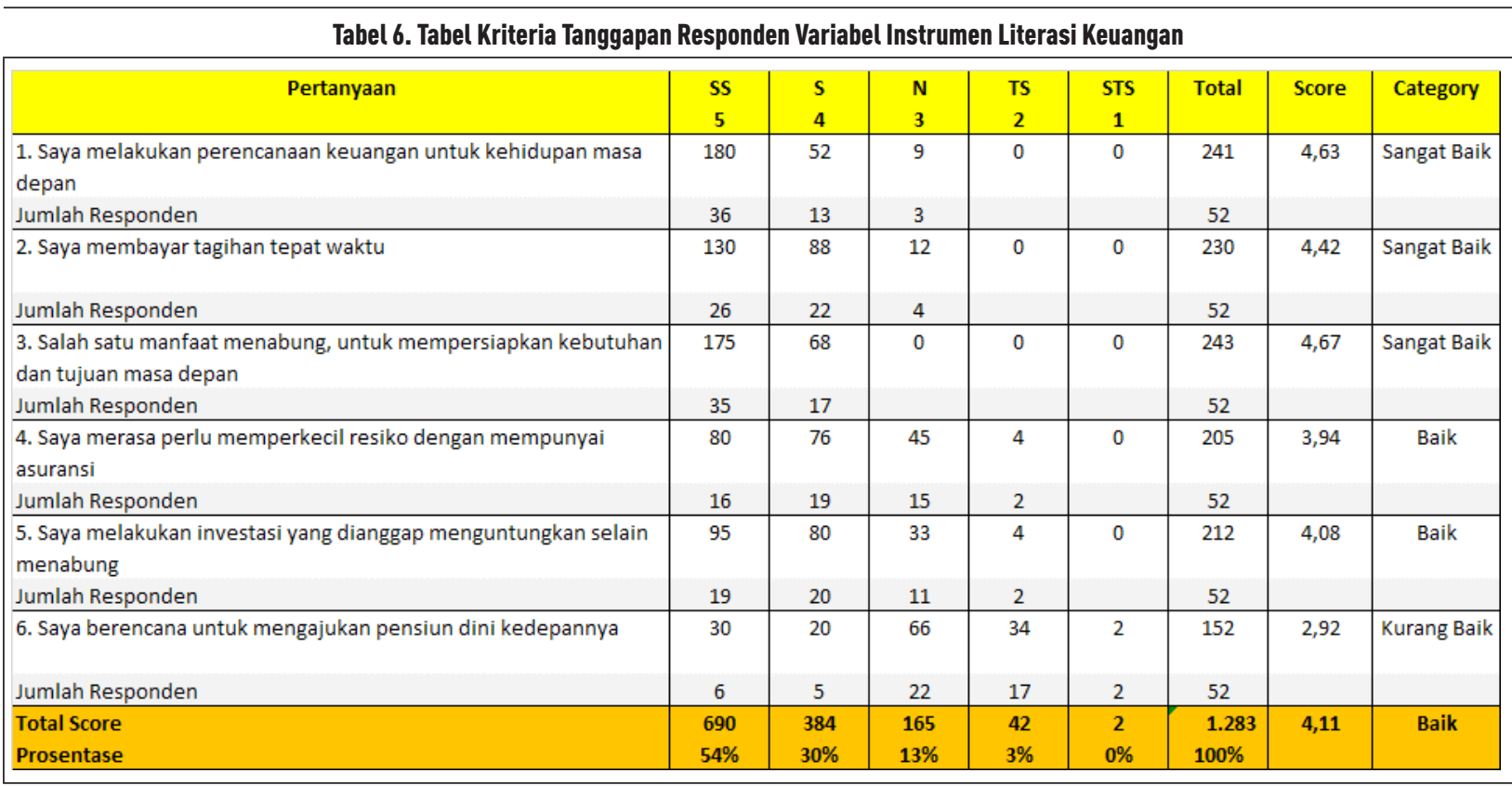

Berdasarkan tabel di atas, tanggapan responden yang paling tinggi yakni item pernyataan manfaat menabung rata-rata skor 4,67 termasuk pada rentang skala sangat baik. Sementara tanggapan responden paling rendah yakni pernyataan mengenai rencana pensiun dini dengan rata-rata skor 2,92. Sedangkan dari kriteria pilihan yang tersedia, maka responden yang menjawab sangat setuju dan setuju sebesar $84,0 \%$, netral $13 \%$ dan responden yang menjawab tidak setuju dan sangat tidak setuju mencapai 3,0\%.

\section{Keputusan Pembelian Pada Media Online}

Kriteria obyek yang diteliti berdasarkan tanggapan responden pada butir pertanyaan variabel instrumen literasi keuangan yang diberikan sebagai berikut:

Tabel 7. Tabel Kriteria Tanggapan Responden Variabel Keputusan Pembelian Pada Media Online

\begin{tabular}{|c|c|c|c|c|c|c|c|c|}
\hline Pertanyaan & $\begin{array}{l}\text { SS } \\
5\end{array}$ & $\begin{array}{l}5 \\
4\end{array}$ & $\begin{array}{l}\mathrm{N} \\
3\end{array}$ & $\begin{array}{c}\text { TS } \\
2\end{array}$ & $\begin{array}{c}\text { STS } \\
1\end{array}$ & Total & Score & Category \\
\hline $\begin{array}{l}\text { 1. Membeli suatu produk melalui online karena lebih efisien } \\
\text { dibanding harus mendatangi tokonya }\end{array}$ & 55 & 88 & 48 & 4 & 1 & 196 & 3,77 & Baik \\
\hline Jumlah Responden & 11 & 22 & 16 & 2 & 1 & 52 & & \\
\hline $\begin{array}{l}\text { 2. Saya akan mereferensikan suatu situs belanja online tertentu } \\
\text { kepada kerabat dekat }\end{array}$ & 40 & 92 & 54 & 6 & 0 & 192 & 3,69 & Baik \\
\hline Jumlah Responden & 8 & 23 & 18 & 3 & & 52 & & \\
\hline $\begin{array}{l}\text { 3. Saya sering menggunakan banyak situs belanja online yang } \\
\text { berbeda untuk mendapatkan keuntungan promo yang ditawarkan }\end{array}$ & 40 & 92 & 54 & 4 & 1 & 191 & 3,67 & Baik \\
\hline Jumlah Responden & 8 & 23 & 18 & 2 & 1 & 52 & & \\
\hline $\begin{array}{l}\text { 4. Harga yang ditawarkan pada situs belanja online lebih murah } \\
\text { daripada pembelian langsung di toko }\end{array}$ & 65 & 72 & 54 & 2 & 2 & 195 & 3,75 & Baik \\
\hline Jumlah Responden & 13 & 18 & 18 & 1 & 2 & 52 & & \\
\hline $\begin{array}{l}\text { 5. Pada umumnya informasi produk dalam situs belanja online } \\
\text { sesuai dengan produk aslinya }\end{array}$ & 10 & 48 & 96 & 8 & 2 & 164 & 3,15 & Kurang Baik \\
\hline Jumlah Responden & 2 & 12 & 32 & 4 & 2 & 52 & & \\
\hline $\begin{array}{l}\text { 6. Transaksi pembayaran saat belanja online cukup aman untuk } \\
\text { dilakukan }\end{array}$ & 25 & 100 & 57 & 4 & 1 & 187 & 3,60 & Baik \\
\hline Jumlah Responden & 5 & 25 & 19 & 2 & 1 & 52 & & \\
\hline Total Score & 235 & 492 & 363 & 28 & 7 & 1.125 & 3,61 & Baik \\
\hline Prosentase & $21 \%$ & $44 \%$ & $32 \%$ & $2 \%$ & $1 \%$ & $100 \%$ & & \\
\hline
\end{tabular}

Berdasarkan tabel di atas, tanggapan responden pada bagian kuesioner terkait keputusan pembelian di mana skor yang paling tinggi yakni item pernyataan bahwa melakukan pembelian online karena dianggap lebih efisien dengan skor 3,77 dan faktor harga yang lebih murah dibanding dengan pembelian langung di toko dengan skala 3,75 termasuk pada rentang skala baik. Sementara 
tanggapan responden paling rendah yakni pernyataan mengenai informasi produk dalam situs online sesuai dengan produk aslinya dengan ratarata skor 3,15. Sedangkan dari kriteria pilihan yang tersedia, maka responden yang menjawab sangat setuju dan setuju sebesar $65 \%$, netral $32 \%$, dan responden yang menjawab tidak setuju dan sangat tidak setuju mencapai $3 \%$.

\section{Pengujian Asumsi Klasik (Uji Prasyarat Data)}

Ujiasumsiklasikdilakukanuntukmemastikan ketepatan data atau keberartian hubungan antara variabel independen dengan variabel dependen. Sehingga pada saat dilakukan uji analisis maka data lebih akurat karena tidak terdapat gejala-gejala asumsi klasik yang menyebabkan data tidak layak sebagai data penelitian. Pengujian dilakukan dengan menggunakan program SPSS versi 24. Dalam penelitian ini uji asumsi klasik yang dilakukan yaitu terdiri dari uji normalitas, uji multikolinearitas, uji autokorelasi, dan uji heterokedastisitas.

\section{Uji Normalitas}

Uji normalitas dilakukan untuk menguji apakah dalam model regresi, variabel dependen dan variabel independen berdistribusi normal atau berdistribusi tidak normal. Model regresi yang baik adalah distribusi data normal atau mendekati normal atau uji normalitas untuk memastikan asumsi bahwa persamaan tersebut berdistribusi normal dilakukan melalui pendekatan alat ukur perhitungan residual variabel bebas $(\mathrm{Y})$.

Uji Normalitas Residual Variabel dapat dideteksi dengan melihat penyebaran titik-titik residual mengikuti arah garis diagonal, dan hal itu sesuai dengan hasil diagram penyebaran yang diolah dengan SPSS versi 24 seperti pada gambar berikut:

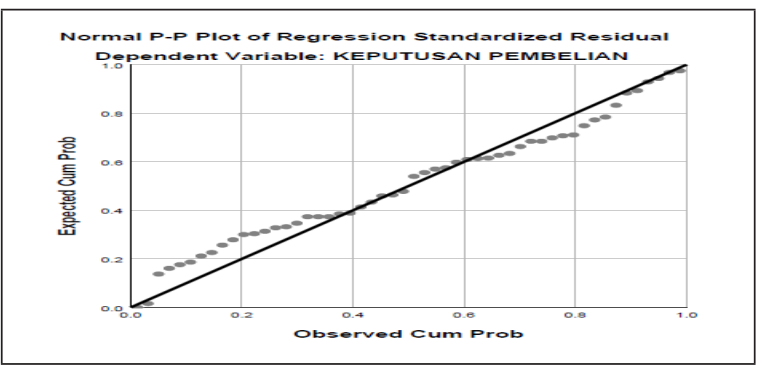

Gambar 2. P-P Plot Uji Normalitas - Diagram Penyebaran Titik Residual
Pada gambar di atas dapat dilihat bahwa grafik normal probability plot menunjukkan pola grafik yang normal. Hal ini terlihat dari titik yang menyebar disekitar garis diagonal dan penyebarannya mengikuti garis diagonal. Oleh karena ini dapat disimpulkan bahwa model regresi memenuhi asumsi normalitas.

\section{Uji Multikolinearitas}

Uji mutlikolinearitas dilakukan untuk meyakini bahwa antar variabel bebas tidak memiliki multikolinearitas atau tidak memiliki hubungan korelasi antara variabel independen. Model regresi yang baik seharusnya tidak terjadi korelasi di antara variabel independen. Uji ini dapat dilakukan dengan melihat nilai Tolerance Value dan Variance Inflation Factor (VIF). Adapun prasyaratnya yaitu jika nilai VIF $>10$ dan nilai tolerance value $>1$ maka terjadi gejala multikoliniearitas dan jika nilai VIF $<10$ dan nilai tolerance value $<1$ maka tidak terjadi gejala multikoliniearitas.

Adapun hasil uji dengan menggunakan SPSS versi 24. sebagai berikut:

\begin{tabular}{|c|c|c|c|}
\hline \multicolumn{4}{|c|}{$\begin{array}{l}\text { Tabel 8. Hasil Pengujian Multikolinearitas Dengan } \\
\text { Collinearity Statistic Keputusan Pembelian } \\
\text { Pada Media Online Sebagai Variabel Dependen }\end{array}$} \\
\hline \multicolumn{4}{|c|}{ Collinearity Diagnostics ${ }^{\mathrm{a}}$} \\
\hline \multirow{2}{*}{\multicolumn{2}{|c|}{ Model }} & \multicolumn{2}{|c|}{ Collinearity Statistics } \\
\hline & & Tolerance & VIF \\
\hline \multirow{4}{*}{1} & (Constant) & & \\
\hline & Tingkat Pendidikan & .786 & 1.272 \\
\hline & Tingkat Literasi & .828 & 1.208 \\
\hline & $\begin{array}{l}\text { Instrumen Literasi } \\
\text { Keuangan }\end{array}$ & .865 & 1.157 \\
\hline
\end{tabular}

Berdasarkan hasil pengujian multikolinieritas pada tabel di atas diperoleh nilai tolerance masing-masing variabel bebas yang diwakilkan dengan nilai Variance Inflation Factor (VIF) variabel tingkat pendidikan sebesar 1,272, tingkat literasi 1,208, dan instrument literasi keuangan 1,157, di mana nilai tersebut kurang dari 10. Dengan demikian model regresi ini tidak ada multikolinearitas. 


\section{Uji Autokorelasi}

Uji autokorelasi dimaksudkan untuk mengetahui ada tidaknya penyimpangan korelasi antar anggota sampel. Untuk mengetahui adanya autokorelasi dilakukan pengujian Durbin-Watson (DW) sebagai berikut:

\begin{tabular}{|c|c|c|c|c|c|}
\hline \multicolumn{6}{c|}{ Tabel 9. Uji Durbin-Watson } \\
\hline Model & R & R Square & $\begin{array}{c}\text { Adjusted } \\
\text { R Square }\end{array}$ & $\begin{array}{c}\text { Std. Error } \\
\text { of the } \\
\text { Estimate }\end{array}$ & $\begin{array}{c}\text { Durbin- } \\
\text { Watson }\end{array}$ \\
\hline 1 & $.681^{\mathrm{a}}$ & .463 & .446 & 2.777 & 1,863 \\
\hline
\end{tabular}

Berdasarkan hasil pengujian pada tabel di atas, model regresi ini tidak ada autokorelasi. Hal ini dibuktikan dengan nilai Durbin-Watson sebesar 1,863 yang berada diantara interval 1.550 -2.460 .

\section{Uji Heteroskedastisitas}

Pengujian heteroskedastisitas dimaksudkan untuk menguji apakah dalam sebuah model regresi terjadi ketidaksamaan varians residual. Salah satu cara untuk mendeteksi ada tidaknya heteroskedastisitas yakni dengan melihat grafik Scatter Plot antara nilai prediksi variabel terikat (ZPRED) dan nilai residualnya (SRESID). Adapun ketentuannya yaitu jika titik-titik membentuk pola tertentu seperti gelombang besar melebar dan menyempit maka telah terjadi heteroskedastisitas. Sedangkan apabila titik-titik menyebar di atas dan di bawah angka 0 pada sumbu $Y$ tanpa membentuk pola tertentu, maka tidak terjadi heteroskedastisitas.

Adapun hasil uji heteroskedastisitas adalah sebagai berikut :

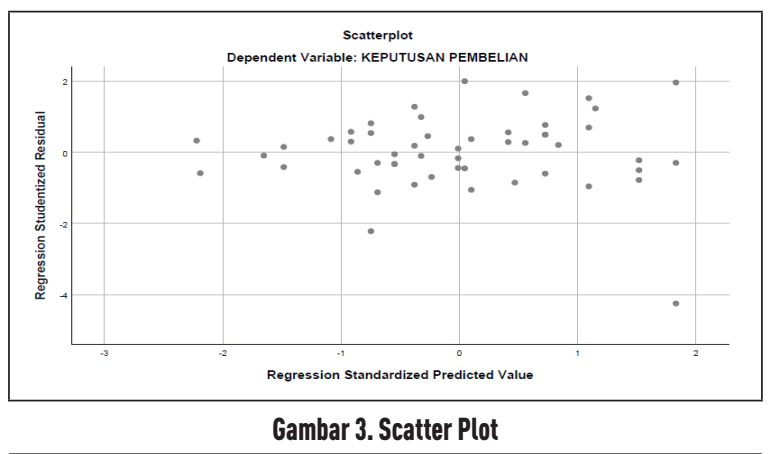

Berdasarkan hasil gambar di atas, titik-titik pada grafik Scatter Plot tidak mempunyai pola penyebaran yang jelas atau tidak membentuk polapola tertentu dan titik-titik tersebut menyebar di atas dan dibawah angka 0 pada sumbu Y. Dengan demikian hal ini menunjukkan bahwa tidak terdapat gangguan heteroskedastisitas pada model regresi sehingga model regresi ini layak dipakai.

\section{Pengujian Analisis}

Analisis verifikatif dimaksudkan untuk mengetahui besaran pengaruh dan menganalisis signifikansi dari perngaruh tersebut. Pada analisis ini dilakukan terhadap pengaruh dari 3 variabel bebas terhadap variabel terikat.

\section{Analisis Regresi}

Uji regresi ini dimaksudkan untuk mengetahui seberapa besar pengaruh variabel dependen terhadap variabel dependen baik secara parsial maupun secara simultan. Berikut ini hasil olahan data regresi dengan SPSS versi 24, sebagaimana pada tabel berikut:

\begin{tabular}{|c|c|c|}
\hline \multicolumn{3}{|c|}{$\begin{array}{l}\text { Tabel 10. Hasil Pengolahan Regresi Berganda, Ujit, Uji F, R Square Terhadap } \\
\left.\text { Variabel Tingkat Pendidikan ( } X_{1}\right) \text {, Tingkat Literasi ( } X_{2} \text { ), Instrumen Literasi } \\
\text { Keuangan }\left(X_{3}\right) \text { Terhadap Keputusan Pembelian Pada Media Online (Y) }\end{array}$} \\
\hline & Uji Linier Berganda & \\
\hline & B & R Square \\
\hline Constant & 12.791 & \multirow{4}{*}{0.044} \\
\hline Tingkat Pendidikan & 0.132 & \\
\hline Tingkat Literasi & 0.331 & \\
\hline Instrumen Literasi Keuangan & 0.287 & \\
\hline
\end{tabular}

Berdasarkan hasil analisis perhitungan regresi pada tabel di atas, maka dapat diperoleh persamaan regresi $\mathrm{Y}=12.791+0,132 \mathrm{X}_{1}+0,331 \mathrm{X}_{2}$ $+0,287 \mathrm{X}_{3}$

Dari persamaan di atas maka dapat disimpulkan sebagai berikut:

1) Nilai konstanta sebesar 12.791 diartikan jika variabel tingkat pendidikan $\left(\mathrm{X}_{1}\right)$, tingkat literasi keuangan $\left(\mathrm{X}_{2}\right)$, dan instrumen literasi keuangan $\left(\mathrm{X}_{3}\right)$ tidak ada, maka telah terdapat nilai keputusan pembelian pada media online (Y) sebesar 12.791 poin.

2) Nilai $X_{1}$ 0,132 diartikan apabila konstanta tetap dan tidak ada perubahan pada tingkat literasi keuangan $\left(\mathrm{X}_{2}\right)$ dan instrumen literasi 
keuangan $\left(\mathrm{X}_{3}\right)$, maka setiap perubahan 1 unit pada variabel tingkat pendidikan $\left(\mathrm{X}_{1}\right)$ akan mengakibatkan terjadinya perubahan pada keputusan pembelian pada media online $(\mathrm{Y})$ sebesar 0,132 poin.

3) Nilai $X_{2}$ 0,331 diartikan apabila konstanta tetap dan tidak ada perubahan pada variabel tingkat pendidikan $\left(\mathrm{X}_{1}\right)$ dan instrument literasi keuangan $\left(\mathrm{X}_{3}\right)$, maka setiap perubahan 1 unit pada variabel instrumen literasi keuangan $\left(\mathrm{X}_{2}\right)$ akan mengakibatkan terjadinya perubahan pada keputusan pembelian pada media online $(\mathrm{Y})$ sebesar 0,331 poin.

4) Nilai $X_{3} \quad 0,287$ diartikan apabila konstanta tetap dan tidak ada perubahan pada variabel tingkat pendidikan $\left(\mathrm{X}_{1}\right)$ dan tingkat literasi keuangan $\left(\mathrm{X}_{2}\right)$, maka setiap perubahan 1 unit pada variabel instrumen literasi keuangan $\left(\mathrm{X}_{3}\right)$ akan mengakibatkan terjadinya perubahan pada keputusan pembelian pada media online $(\mathrm{Y})$ sebesar 0,287 poin.

\section{Analisis Koefisien Determinasi (R Square)}

Analisis koefisien determinasi dimaksudkan untuk mengetahui persentase kekuatan hubungan antara variabel independen terhadap variabel dependen, baik secara parsial maupun simultan. Dalam penelitian ini yaitu variabel tingkat pendidikan $\left(\mathrm{X}_{1}\right)$, tingkat literasi $\left(\mathrm{X}_{2}\right)$, dan instrumen literasi keuangan $\left(\mathrm{X}_{3}\right)$ terhadap keputusan pembelian pada media online (Y). Hasil perhitungan koefisien determinasi yang diolah dengan program SPSS versi 24 pada tabel 10 diperoleh nilai $R$-square sebesar 0,044. Dengan demikian dapat disimpulkan variabel tingkat pendidikan $\left(\mathrm{X}_{1}\right)$, tingkat literasi $(\mathrm{X} 2)$, dan instrumen literasi keuangan $\left(\mathrm{X}_{3}\right)$ terhadap keputusan pembelian pada media online $(\mathrm{Y})$ sebesar $4,4 \%$. Sedangkan sisanya sebesar $96 \%$ dipengaruhi oleh faktor lain yang tidak dilakukan penelitian.

\section{Analisis Koefisien Korelasi ( $r$ )}

Analisis koefisien korelasi dimaksudkan untuk mengetahui tingkat kekuatan hubungan antara variabel independen terhadap variabel dependen. Hasil pengolahan data sebagai berikut:

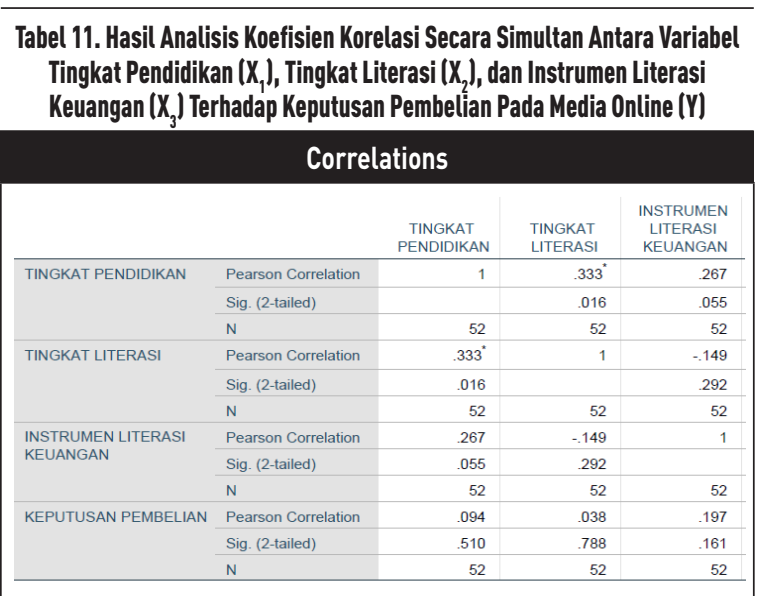

Berdasarkan hasil pengujian pada tabel di atas, diperoleh nilai $\mathrm{R}$ (koefisien korelasi) ketiga variabel bebas tidak memiliki korelasi yang kuat pada keputusan pembelian pada media online. Hal ini terlihat dari koefisien Pearson Correlation masing-masing variabel bebas yaitu variabel tingkat pendidikan $\left(\mathrm{X}_{1}\right)$ 0,510, tingkat literasi keuangan $\left(\mathrm{X}_{2}\right)$ 0,788, dan instrumen literasi keuangan $\left(\mathrm{X}_{3}\right) 0,161$.

\section{Pengujian Hipotesis}

Pengujian hipotesis untuk melihat pengaruh variabel bebas terhadap variabel terikat baik secara partial maupun simultan dilakukan uji $t$ dan F dengan hasil pengujian pada tabel berikut:

\begin{tabular}{|c|c|c|c|c|}
\hline \multicolumn{5}{|c|}{$\begin{array}{l}\text { Tabel 10. Hasil Pengolahan Regresi Berganda, Uji t, Uji F, R Square Terhadap } \\
\text { Variabel Tingkat Pendidikan }\left(X_{1}\right) \text {, Tingkat Literasi ( } X_{2} \text { ), Instrumen Literasi } \\
\text { Keuangan }\left(X_{3}\right) \text { Terhadap Keputusan Pembelian Pada Media Online (Y) }\end{array}$} \\
\hline & \multicolumn{2}{|c|}{$\begin{array}{l}\text { Uji t Pada Setiap } \\
\text { Variabel Bebas }\end{array}$} & \multicolumn{2}{|c|}{ Uji F } \\
\hline & $t$ & Sig & $F$ & Sig \\
\hline Constant & & & 0.735 & 0.536 \\
\hline Tingkat Pendidikan & 0.664 & 0.51 & & \\
\hline Tingkat Literasi & 0.27 & 0.778 & & \\
\hline Instrumen Literasi Keuangan & 1.424 & 0.161 & & \\
\hline
\end{tabular}

\section{Pengujian Hipotesis Secara Parsial (Uji t)}

\section{Tingkat Pendidikan $\left(\mathrm{X}_{1}\right)$ Pada}

\section{Keputusan Pembelian Pada Media Online (Y)}

Berdasarkan hasil pengujian pada tabel 12 di atas diperoleh nilai $\mathrm{t}_{\text {hitung }}<\mathrm{t}_{\text {tabel }}$ atau $(0.664<$ 1.675). Hal tersebut juga diperkuat dengan nilai $\rho$ value $>$ Sig.0,05 atau $(0,510>0,05)$. Hal ini menunjukkan, tidak terdapat pengaruh yang signifikan secara parsial antara tingkat pendidikan dengan keputusan pembelian pada media online. 
Tingkat Literasi Keuangan $\left(\mathrm{X}_{2}\right)$ Pada

Keputusan Pembelian Pada Media Online (Y)

Berdasarkan hasil pengujian pada tabel 12 diperoleh nilai $\mathrm{t}_{\text {hitung }}<\mathrm{t}_{\text {tabel }}$ atau $(0.270<1.675)$. Hal tersebut juga diperkuat dengan nilai $\rho$ value $>$ Sig.0,05 atau $(0,788>0,05)$. Hal ini menunjukkan, tidak terdapat pengaruh yang signifikan secara parsial antara tingkat literasi keuangan dengan keputusan pembelian pada media online.

\section{Tingkat Instrumen Literasi Keuangan $\left(\mathbf{X}_{1}\right)$ Terhadap Keputusan Pembelian Pada Media Online (Y)}

Berdasarkan hasil pengujian pada tabel 12 diperoleh nilai $\mathrm{t}_{\text {hitung }}<\mathrm{t}_{\text {tabel }}$ atau $(1,424<1.675)$. Hal tersebut juga diperkuat dengan nilai $\rho$ value $>$ Sig.0,05 atau $(0,161>0,05)$. Dengan demikian maka $\mathrm{H}_{0}$ diterima dan $\mathrm{H}_{1}$ ditolak. Hal ini menunjukkan, tidak terdapat pengaruh yang signifikan secara parsial antara instrumen literasi keuangan dengan keputusan pembelian pada media online.

\section{Pengujian Hipotesis Secara Simultan (Uji F)}

Untuk pengujian pengaruh antara variabel tingkat pendidikan $\left(\mathrm{X}_{1}\right)$, tingkat literasi $\left(\mathrm{X}_{2}\right)$, dan instrumen literasi keuangan $\left(\mathrm{X}_{3}\right)$ terhadap keputusan pembelian pada media online $(\mathrm{Y})$ dengan uji statistik F (uji simultan) dengan signifikansi $5 \%$. Berdasarkan pada hasil pengujian pada tabel 12 diperoleh nilai $\mathrm{F}_{\text {hitung }}<\mathrm{F}_{\text {tabel }}$ atau $(0,735<2,80)$. Hal ini juga diperkuat dengan $\rho$ value $>$ Sig.0,05 atau $(0,536>0,05)$. Hal ini menunjukkan, tidak terdapat pengaruh signifikan secara simultan antara variabel tingkat pendidikan $\left(\mathrm{X}_{1}\right)$, tingkat literasi keuangan $\left(\mathrm{X}_{2}\right)$, dan instrumen literasi keuangan $\left(\mathrm{X}_{3}\right)$ terhadap keputusan pembelian pada media online (Y).

\section{Pembahasan}

Dalam penelitian ini dilakukan pengujian terhadap sampel yang diperoleh dari survei yang dilakukan terhadap masyarakat Kota Tangerang Selatan sebanyak 52 orang sudah memenuhi jumlah minimal responden sebanyak 44 orang dengan alpha sebesar $15 \%$. Responden yang mengisi survei untuk jenis kelamin laki-laki sebanyak 18 orang atau sebesar 35\%. Sedangkan jenis kelamin perempuan sebanyak 34 orang atau sebesar $65 \%$.

Sedangkan untuk tingkat pendidikan, dari 52 responden dengan tingkat pendidikan S3 sebanyak 1 orang atau sebesar 2\%, S2 sebanyak 16 orang atau sebesar $31 \%$, S1 sebesar 9 orang atau sebesar 17\%, SMA sebanyak 20 orang atau sebesar $38 \%$, dan SMP sebanyak 6 orang atau sebesar $12 \%$.

Untuk tingkat literasi keuangan, responden dengan Well Literate 2\% dari total responden, Suff Literate 33\% dari total responden, Less Literate $63 \%$ dari total responden, dan Not Literate 2\% dari total responden. Sehingga \% yang terbanyak adalah Less Literate sebesar 63\%.

Efisiensi dan harga yang lebih murah merupakan faktor yang dianggap paling mempengaruhi responden dalam pengambilan keputusan pembelian. Hal ini disimpulkan dari jumlah skor yang paling tinggi pada kuesioner keputusan pembelian pada media online merupakan item pernyataan pembelian online dianggap lebih efisien dengan skor 3,77. Kemudian faktor harga yang lebih murah dibanding dengan pembelian langsung di toko dengan skala 3,75 termasuk pada rentang skala baik.

Tanggapan responden paling rendah yakni pada pernyataan mengenai informasi produk dalam situs online sesuai dengan produk aslinya dengan rata-rata skor 3,15 . Sedangkan dari kriteria pilihan yang tersedia, maka responden yang menjawab sangat setuju dan setuju sebesar $65 \%$, netral 32\% serta responden yang menjawab tidak setuju dan sangat tidak setuju mencapai 3\%.

Berdasarkan uji asumsi klasik yang dilakukan yaitu uji normalitas, uji multikolinearitas, uji autokorelasi, dan uji heterokedastisitas, diperoleh hasil data memenuhi uji asumsi klasik tersebut. Sementara itu untuk uji regresi linier berganda memberikan hasil tingkat pendidikan $\left(\mathrm{X}_{1}\right)$, tingkat literasi keuangan $\left(\mathrm{X}_{2}\right)$, dan instrumen literasi keuangan $\left(\mathrm{X}_{3}\right)$ berpengaruh positif terhadap keputusan pembelian pada media online $(\mathrm{Y})$. Dengan demikian, kenaikan ketiga variabel bebas tersebut akan menaikkan variabel terikat.

Sedangkan untuk uji signifikan dengan uji $\mathrm{t}$ dan uji $\mathrm{F}$ diperoleh hasil tidak ada pengaruh antara variabel tingkat pendidikan $\left(\mathrm{X}_{1}\right)$, tingkat 
literasi keuangan $\left(\mathrm{X}_{2}\right)$, dan instrumen literasi keuangan $\left(\mathrm{X}_{3}\right)$ tidak terdapat pengaruh pada keputusan pembelian pada media online secara signifikan baik secara parsial maupun secara simultan. Hal ini juga diperkuat dengan nilai $R$ Square hanya sebesar 0.044 . Sehingga berdasarkan hasil yang diperoleh dari penelitian ini, kebutuhan pembelian pada media online saat ini tidak dipengaruhi oleh tingkat pendidikan, pengetahuan literasi keuangan, dan instrumen literasi keuangan.

\section{SIMPULAN}

Dari hasil kuesioner terkait literasi keuangan, variabel yang dianggap penting dalam instrumen literasi keuangan yaitu manfaat menabung di mana responden memberikan tanggapan paling rendah yakni terkait rencana pensiun dini. Sementara faktor yang dianggap paling penting dalam penentuan keputusan pembelian online yaitu anggapan pembelian online lebih efisien dan faktor harga yang lebih murah dibanding dengan pembelian langsung di toko. Sementara faktor yang dianggap membuat pembeli tidak melakukan pembelian melalui online karena adanya informasi yang diberikan produk dalam situs online tidak sesuai dengan produk aslinya.

Pengujian uji t dan F memberikan kesimpulan bahwa variabel tingkat pendidikan $\left(\mathrm{X}_{1}\right)$, tingkat literasi keuangan $\left(\mathrm{X}_{2}\right)$, dan instrumen literasi keuangan $\left(\mathrm{X}_{3}\right)$ tidak terdapat pengaruh signifikan baik secara parsial maupun secara simultan terhadap keputusan pembelian pada media online (Y) pada masyarakat di Kota Tangerang Selatan. Hal ini diperkuat dengan nilai $R$ Square hanya 0.044 , sehingga pengaruh ketiga variabel tersebut sangat kecil terhadap keputusan pembelian pada media online.

Hasil penelitian juga sejalan dengan adanya fenomena perubahan pola konsumsi masyarakat dalam memenuhi kebutuhannya dengan pembelian melalui online karena kemudahan yang ditawarkan seperti efisiensi, harga yang ditawarkan lebih murah, variasi produk yang beragam, dan kemudahan tanpa hambatan yang berarti. Dengan demikian masyarakat dari berbagai ting- kat pendidikan maupun pengetahuan terkait keuangan tertarik melakukan pembelian pada media online. Diharapkan penelitian sejenis dapat dilakukan untuk wilayah yang lebih luas atau wilayah lain di Indonesia dengan sampel penelitian yang lebih besar. Hal ini dimaksudkan untuk memberikan gambaran, apakah terjadi fenomena yang sama dengan variabel yang diteliti pada penelitian ini.

\section{DAFTAR PUSTAKA}

Assauri, Sofjan. (2013). Manajemen Pemasaran Dasar Konsep dan Strategi. Jakarta: Rajawali Pers.

Baubonienè, Ž., \& Gulevičiūtè, G. (2015). E-Commerce Factors Influencing Consumers 'Online Shopping Decision.

Christoper, S. W. H., \& Kristianti, I. (2020). Hubungan E-Commerce dan Literasi Keuangan Terhadap Kelangsungan Usaha di Boyolali. Jurnal Akuntansi ISSN, 2303, 0356.

Danuza, D. M., \& Herieningsih, S. (2018). Hubungan Intensitas Mengakses Online Shop dan Tingkat Kepercayaan Rekomendasi Peer Group dengan Pembelian Impulsif Secara Online. Interaksi Online, 6(2), 28-37.

Fattah, F. A., Indriayu, M., \& Sunarto, S. (2018). Pengaruh Literasi Keuangan dan Pengendalian Diri Terhadap Perilaku Konsumtif Siswa SMA Muhammadiyah 1 Karanganyar. BISE: Jurnal Pendidikan Bisnis dan Ekonomi, $4(1)$.

Fahmi, Irham. (2014). Manajemen Strategis Teori dan Aplikasi. Bandung: Alfabeta.

Fattah, F. A., Indriayu, M., \& Sunarto, S. (2018). Pengaruh Literasi Keuangan dan Pengendalian Diri Terhadap Perilaku Konsumtif Siswa SMA Muhammadiyah 1 Karanganyar. BISE: Jurnal Pendidikan Bisnis dan Ekonomi, 4(1).

Ahmad, M. (2018). Online Shopping Behavior Among University Students: Case Study Of Must University. Advances in Social Sciences Research Journal, 5(4).

Lo, L. Y. S., Lin, S. W., \& Hsu, L. Y. (2016). Motivation for online impulse buying: A twofactor theory perspective. International Jour- 
nal of Information Management, 36(5), 759772.

Pratiwi, I. (2017). Pengaruh Literasi Ekonomi, Kelompok Teman Sebaya dan Kontrol Diri Terhadap Perilaku Pembelian Impulsif Untuk Produk Fashion di Online Shop Pada Mahasiswa Jurusan Pendidikan Ekonomi Undiksha. Jurnal Pendidikan Ekonomi Undiksha, 9(1), 98-107.

Otoritas Jasa Keuangan. (2017). Strategi Nasional Literasi Keuangan (Revisit 2017). Jakarta : Otoritas Jasa Keuangan (publikasi online).

Prasetyo, B. \& Jannah, L. M. (2012). Metode Penelitian Kuantitatif : Teori dan Aplikasi. Jakarta: PT RajaGrafindo Persada.

Prasetyaningsih, R. F. (2019). Pengaruh Tingkat Literasi Keuangan, Status Sosial Ekonomi Orang Tua, Jenis Kelamin dan Jurusan Terhadap Pola Konsumsi Mahasiswa Fakultas Ekonomi Universitas Negeri Yogyakarta. Jurnal Pendidikan dan Ekonomi, 8(4), 335-345.

Putri, S. F., Widodo, J., \& Martono, S. (2016). Pengaruh Literasi Keuangan Melalui Rasionalitas Terhadap Perilaku Konsumtif (Studi Kasus Siswa Kelas XI Ilmu Sosial SMA Negeri se-Kota Semarang). Journal of Economic Education, 5(2), 179-192.

Rafidah, I. (2017). Analisis Keamanan Kemudahan dan Kepercayaan terhadap keputusan Pembelian Secara online di Lazada. Jurnal Ilmu dan Riset Manajemen (JIRM), 6(2).

Romadoni, R. (2017). Pengaruh Status Sosial Ekonomi dan Pendidikan Pengelolaan Ke- uangan di Keluarga terhadap Literasi Keuangan Siswa SMK Negeri 1 Surabaya. Jurnal Ekonomi Pendidikan dan Kewirausahaan, 3(1), 22-34.

Sari, Ratna Candra, and PL Rika Fatimah. (2017). "Bringing voluntary financial education in emerging economy: Role of financial socialization during elementary years." The Asia-Pacific Education Researcher 26.3-4: 183-192.

Sugiyono. (2014). Metode Penelitian Kuantitatif Kualitatif dan R\&D. Bandung: Alfabeta.

Schiffman \& Kanuk, L. (2010). Consumer Behaviour. New Jeraey: Prentice Hall.

Santoso, G., \& Triwijayati, A. (2018). Gaya Pengambilan Keputusan Pembelian Pakaian Secara Online pada Generasi Z Indonesia. Jurnal Ilmu Keluarga \& Konsumen, 11(3), 231-242.

Soekanto, S. (2013). Sosiologi Suatu Pengantar, edisi revisi, cetakan ke-45. Jakarta: Raja Grafindo.

Susanti, A., \& Rikah, R. (2020). Penggunaan Media Sosial Instagram dan Literasi Keuangan Terhadap Perilaku Konsumtif Berbelanja Online Generasi Milenial. JAB (Jurnal Akuntansi \& Bisnis), 6(01).

Persada Soyomukti, N. (2013). Pengantar Sosiologi: Dasar Analisis, Teori, \& Pendekatan Menuju Analisis Masalah-Masalah Sosial, Perubahan Sosial, \& Kajian Strategis. Yogyakarta: ArRuzz Media. 